\title{
EKSPRESI SENI MASYARAKAT TRADISIONAL DESA ADAT PENGLIPURAN BANGLI SEBAGAI SARANA PEMUJAAN KEPADA TUHAN (KAJAN BENTUK, FUNGSI, DAN MAKNA)
}

\begin{abstract}
I Nengah Duija ${ }^{1}$
Abstract : In Balinese Culture art is substantial because it closely relates to the system of belief especially Hindu religion. Thus art is having inner power that is the spirit of the purity of Hindu itself. Therefore functionally art in Bali can be categorized into: seni wali, bebali and balih-balihan. The intensity of art activities relate to the ritualistic performance of Balinese Hindu society. In Balinese traditional society art activities relate to religious ritual are frequently performed even melted into the life of their rites.

Likewise in the village of Adat Penglipuran Bangli, has expressed that art as an act of worship in the form of sacred Baris Dance. The performance of sacred Baris dance in the village of Adat Penglipuran has form, function and meaning pertaining to worship, both to ancestors (cosmic axis) at Bayung Gede Kintamani and to God. The aesthetic concept that is used as a mean of worship borne theoaesthetic term. Because of having those functions and meaning this sacred tradition survive. Besides that, this sacred Baris Dance as honor to geographical reality that has its upper reach at mountain, so it's value-oriented is on war myth, fertility, water, etc. Thus the artistic expression of Penglipuran society as worship rites toward the Creator.
\end{abstract}

Key Words: Artistic Expression, Traditional Society, Mean of Worship.

Berbicara tentang seni atau kesenian, maka tidak dapat dilepaskan dari konteks kebudayaan yang melahirkan seni itu sendiri. Pertautan ini disebabkan oleh karena seni atau kesenian merupakan bagian dari tujuh unsur kebudayaan yang bersifat universal, artinya sekecil atau sesederhana apapun kebudayaan suatu suku bangsa unsur kesenian ada di dalamnya. Menurut C. Kluckhohn, setiap kebudayaan suku bangsa terdapat tujuh unsur kebudayaan yang disebut cultural universal, yaitu meliputi: (1) bahasa, (2) sistem

${ }^{1}$ I Nengah Duija adalah Dosen di Fakultas Brahma Widya (Filsafat dan Teologi), Institut Hindu Dharma Negeri Denpasar. 
pengetahuan, (3) organisasi sosial, (4) sistem peralatan hidup dan teknologi, (5) sistem mata pencaharian hidup, (6) sistem religi, dan (7) kesenian (Koen tjaraningrat, 1990:203-204). Kesenian terdiri dari (a) seni patung, (2) seni re lief, (c) seni lukis dan gambar, (d) seni rias, (e) seni vokal, (f) seni instrumental, (g) seni kesusastraan, (h) seni drama (Koentjaraningrat, 1985: 8).

Di Bali seni pertunjukan mengalami zaman keemasan sejak tahun 70an, dimana seni pertunjukan di Bali cukup beragam mulai dari seni pertunjukan yang bersifat seni Wali seperti Sanghyang, Rejang, seni Bebali yakni Gambuh, Wayang Wong, dan seni Balih-Balihan yakni Legong, Arja, Kebyar (Bandem,1996:62). Selain itu perlu diketahui bahwa seni pertunjuk-an tradisional dalam kesenian Bali meliputi: dramatari Gambuh, Wayang $\mathrm{Ku}-$ lit, dramatari Topeng atau Prembon, Calonarang, Operatari Arja, Sendratari dan Drama Gong (Dibia, 1993:137).

Salah satu seni keagamaan (wali), yaitu Tari Baris adalah merupakan salah satu bentuk tari yang mencerminkan nilai-nilai spiritual dan watak kepahlawanan, yang sampai saat ini masih tetap digemari dan dilestarikan oleh masyarakat Bali pada umumnya. Tari Baris adalah merupakan salah satu seni budaya yang masih hidup di Bali, dan di dalam keterpaduan unsur-unsur seni itu, maka unsur seni tari yang paling dominan. Karena seni tari itu tdak lepas dari kehidupan masyarakat Hindu di Bali yang selalu mempunyai keterkaitan dengan pelaksanaan upacara-upacara keagamaan.

Salah satu desa di Kabupaten Bangli yang masih kental ekspresi seni keagamaannya adalah Desa Adat Penglipuran. Desa Adat ini yang terdapat di wilayah Kecamatan Bangli, Kabupaten Daerah Tingkat II Bangli. Desa Adat Penglipuran adalah merupakan salah satu objek pariwisata di Kabupaten Bangli dengan luas wilayah $\pm 70 \mathrm{Ha}$, dengan jumlah penduduk \pm 800 orang. Desa Adat Penglipuran ditunjang dengan adanya beberapa tempat suci (pura) dan pementasan beberapa tari-tarian sakral pada saat upacara keagamaan. Pelaksa-naan upacara keagamaan yang diselenggarakan di Pura Penataran dan Pura Puseh Desa Adat Penglipuran selalu dilengkapi dengan pementasan tari-tarian sakral, seperti : (1) Tari Baris Jojor, (2) Tari Baris Presi, (3) Tari Baris Bedil. Pementasan tari-tarian sakral, seperti : Tari Baris Jojor, Baris Presi, Baris Bedil, di samping sebagai tari penyelenggara upacara Dewa Yadnya di Desa Adat Penglipuran, juga sering dipentaskan pada saat penyelenggaraan upacara tertentu di Pura Kehen Kabupaten Bangli dan di Pura Besakih Kabupaten Karangasem.

Untuk itu pertanyaan yang dapat dirumuskan adalah : 1) bagaimana bentuk ekspresi seni di Desa Adat Penglipuran sebagai sarana pemujaan kepada Tuhan ? 2) apakah fungsi pementasan seni tari-tarian sakral bagi Desa Adat Penglipuran dalam kaitannya dengan pemujaan kepada Tuhan? 3) apa makna pementasan seni sakral di desa Adat Penglipuran yang berkaitan dengan agama Hindu dan lingkungannya sekitarnya ? 
Ekspresi Seni Masyarakat... (I Nengah Duija)

\section{BENTUK EKSPRESI SENI DI DESA ADAT PENGLIPURAN SEBAGAI PEMUJAAN}

Dalam pelaksanaan penelitian ini diperoleh data tentang ekspresi pementasan seni Tari Baris Sakral (seni keagamaan), sebagai hasil dari suatu karya seni. Pementasan Tari Sakral ini terdiri atas unsur-unsur seni, di antara unsur-unsur seni itu adalah : seni tari, seni musik atau kerawitan, seni rias, dan busana. Dengan demikian, data-data yang sudah didapat sebagai bentuk kegiatan ekspresi seni sebagai bentuk pemujaan tersebut akan diuraikan berikut ini.

Keberadaan dari Tari Baris Sakral sebagai salah satu ekspresi seni sebagai sarana pemujaan itu tidak terlepas dari keberadaan Desa Adat Penglipuran. Munculnya Tari Baris Sakral ini adalah untuk mendukung proses upacara Dewa Yadnya, yaitu sebagai tari penyelenggara upacara yang ditujukan kepada Tuhan. Proses transformasinya sendiri dilaksanakan oleh Desa Adat dengan menggunakan anggota masyarakat baik yang sudah berkeluarga maupun yang belum berkeluarga sebagai personil pendukung. Tari Baris Sakral tetap untuk sampai sekarang walaupun terjadi penggantian generasi, karena awig-awig Desa Adat yang mengatur adanya proses regenerasi seni keagamaan, maka tari Baris sakral itu tetap lestari sampai sekarang.

\section{Pendukung Tari Baris Sakral sebagai Bentuk Pemertahanan}

Sesuai dengan awig-awig atau peraturan yang berlaku di Desa Adat Penglipuran, maka anggota masyarakat sebagai pendukung dan pelaksana kegiatan pementasan Tari Baris Sakral, baik sebagai penari maupun sebagai penabuh. Dalam pelaksanaan piodalan, yang banyak terlibat "ngaturang ayah" mulai dari persiapan sampai dengan pelaksanaan upacara. Pada umumnya baik anggota masyarakat biasa, penari maupun penabuh ikut terlibat sesuai dengan pembagian tugas, yang tetap dikoordinir oleh prajuru Desa Adat Penglipuran.

Secara umum para penari dapat melibatkan diri dalam kegiatan upa cara, karena adanya rasa ingin "ngayah" ke pura, secara sosiologis dan psikologis keinginan itu sudah ada, terutama dalam jiwa mereka sebagai perwujudan dari asas kebersamaan dan asas pengabdian sehingga kalau tidak dapat "ngayah" sepertinya ada perasaan bersalah dalam diri mereka.

\section{Penari (Pregina) dan Penabuh dan Jenis Tarian}

Para penari Baris Sakral yang ada di Desa Adat Penglipuran, yang terdiri dari penari Baris Jojor berjumlah enam belas orang, mereka adalah anggota masyarakat yang belum kawin yang bergabung dalam organisasi Sekaa Teruna Teruni. Penari Baris Presi berjumlah empat orang, sedangkan keanggotaan sekaa penari Baris Presi ini berjumlah dua belas orang dan 
mereka adalah yang sudah berkeluarga, tetapi bersetatus "pengahayah pengerob". Penari Baris Bedil berjumlah enam belas orang, dan keanggotaan sekaa Baris Bedil ini berjumlah dua puluh orang. Mereka adalah sudah berkeluarga, tetapi berstatus "pengayah pengerob". Di samping "pengayah pengerob" untuk Penari Baris Presi dan Baris Bedil dapat juga ditarikan oleh "pengayah pengarep" yang memang mempunyai bakat sebagai penari Baris tersebut. Para penabuh juga dilakukan oleh masyarakat itu sendiri baik "pengayah pengerob" maupun "pengarep" yang memang mempunyai bakat atau keahlian sebagai penabuh yang jumlahnya empat puluh orang yang biasanya disesuaikan dengan jumlah perangkat musik atau gambelan yang ada. Adapun jenis tari-tarian sakral yang ada di Desa Adat Penglipuran:

1) Tari Baris Jojor adalah tari Baris yang ditarikan oleh sekaa Teruna atau mereka yang belum berkeluarga atau belum kawin dengan bersenjataan jojor atau tombak dan biasanya ditarikan oleh 16 orang.

2) Tari Baris Bedil adalah tari Baris yang ditarkan oleh orang yang sudah berkeluarga atau sudah kawin yag bersenjataan bedil yang dibuat kayu yang menyerupai bedil. Tari Baris Bedil biasanya ditarikan oleh 16 orang Penari Baris Bedil.

3) Tari Baris Presi adalah tari Baris yang ditarikan oleh orang yang sudah berkeluarga atau sudah kawin. Tari Baris Presi ini para penarinya menggunakan Presi sebagai senjata, yang ditarikan oleh 4 orang penari Baris Presi.

Ketiga jenis tarian Baris tersebut di atas adalah merupakan tari-tarian sakral yang hanya dapat ditarikan oleh orang laki-laki saja, yang dalam pementasannya diiringi dengan gamelan gong gede oleh sekaa gong Desa Adat Penglipuran.

\section{Sistem Regenerasi Sebagai Wadah Transformasi Nilai}

Adapun upaya pelestarian melalui sistem regenerasi ekspresi seni dimaksud dilakukan oleh Desa Adat Penglipuran sebagai sebuah pemertahanan nilai spiritualitas masyarakatnya adalah melalui: (1) Dengan membentuk "sekaa-sekaa" tari Baris Sakral yang keangotaannya diambil dari "pengayah pengerob" yang memang wajib untuk menjadi anggota "sekaa" Tari Baris Sakral. Di samping itu, penari Baris dapat juga diambil dari "pengayah pengarep", bagi mereka yang mempunyai bakat sebagai penari $\mathrm{Ba}$ ris. (2) Dengan membentuk "sekaa gong" sebagai pendukung pementasan tari sakral, keanggotaannya diambil dari pengayah pengerob yang memang wajib untuk menjadi anggota Sekaa Gong. Di samping itu, juga dapat diambil dari pengayah yang menekuni seni tabuh atau gambelan gong gede.

Di samping membentuk "sekaa-sekaa" Tari Baris dan Sekaa Gong juga pementasan tari-tarian sakral tersebut, di beberapa tempat lainnya sebagai desa bebanuan, Desa Adat Penglipuran, yaitu di Desa Bayung Gede Kecamatan Kintamani dan Desa Adat Sulahan Kecamatan Susut. Pemen- 
tasan ini sebagai bentuk ekspresi seni keagamaan (seni sakral) agar keberlanjutannya dapat tetap dipertahankan hingga saat ini. Ini berarti sistem regenerasinya melalui jalur informal dan non-formal khususnya melalui ranah tradisi adat Desa Penglipuran. Awig-awig adat telah memberikan ramburambu transformasi nilai seni keagamaan ini secara hukum adat, sehingga memiliki kekuatan dalam pembinaan generasi muda untuk menekuni seni keagamaan ini.

Dalam konteks teori estetika Hindu Bali, seperti yang dijelaskan pada landasan teori di depan, maka transformasi nilai seni keagamaan akan sampai pada kepuasan estetik jika telah terjadi keselarasan antara irama, gamelan, tenaga, penghayatan atas peran, dialog dan ekspresi atau karakter tokoh yang diperankan. Sebagai penumbuh kekuatan semua itu di landasi oleh konsep tiga wisesa, yakni satyam, siwam, sundaram; sebuah keindahan yang suci (penghayatan kepada yang Maha Pencipta) dan secara etika benar atau mengandung kebenaran (pesan). Ketiga konsep ini merupakan totalitas estetik yang tidak hanya menyentuh aspek estetika ragawi (fisik) namun juga estetika metafisik. Di situlah seni sebagai sarana pemujaan kepada dewa keindahan yang abadi (Tuhan) untuk mencapai hubungan yang seimbang secara kosmologis (baca: estetika kosmologi). Sang seniman melakukan kontemplasi estetik untuk dapat memohon kekuatan atas peran yang dimainkan, sehingga karakter tokoh yang dimainkan menjadi lengut, adung, pangus, serta mataksu. Inilah konsep sistem transformasi nilai seni keagamaan yang sesungguhnya penting untuk ditularkan melalui tradisi adat khususnya awig-awig sebagaimana yang terjadi di Desa Adat Penglipuran ini.

\section{FUNGSI EKSPRESI SENI DI DESA ADAT PENGLIPURAN SEBAGAI SARANA PEMUJAAN}

Menurut G.P Kurath sebagaimana dikutip oleh Soedarsono (1985: 18) menyebutkan 14 fungsi tari, yaitu: (1) untuk upacara pubertas, (2) upacara inisiasi, (3) percintaan, (4) persahabatan, (5) upacara perkawinan, (6) pekerjaan, (7) upacara kesuburan, (8) perbintangan, (9) upacara perburuan, (10) lawakan, (11) perang, (12) sebagai Tontonan. Apabila dikaji secara historis, bahwa pada zaman teknologi modern ini secara garis besar fungsi seni pertunjukan (tari) dalam kehidupan manusia bisa dikelompokkan menjadi tiga: (1) sebagai sarana upacara, (2) sebagai hiburan pribadi, dan (3) sebagai tontonan (Ibid,1985:18). Tari Baris Sakral yang ada di Desa Adat penglipuran berfungsi sebagai sarana upacara sebagai fungsi pokok, di samping dapat dilihat dalam beberapa aspek yang meliputi:

\section{Fungsi Tari Baris Sakral Sebagai Sarana Upacara}

Tari Baris Sakral yang ada di Desa Adat Penglipuran ada tiga jenis, 
yaitu Tari Baris Jojor, Tari Baris Presi dan Tari Baris Bedil. Ketiga tari Baris tersebut adalah berfungsi sebagai tari penyelenggara upacara Dewa Yadnya. Pementasan Tari Baris Sakral tersebut di samping memperlihatkan unsur seni tari, juga tidak kalah pentingnya bahwa semua jenis tari Baris sakral itu dalam fungsinya sebagai tari penyelenggara upacara Dewa Yadnya adalah mempunyai nilai-nilai spiritual yang sangat dalam, yaitu bahwa antara pementasan tari Baris sakral dengan pelaksanaan upacara Dewa Yadnya sebagai satu kesatuan yang utuh. Seperti yang telah dijelaskan di atas, salah satu fungsi musik dan tari dari deretan fungsi itu dapat ditegaskan, yakni fungsi persembahan simbolis dan fungsi upacara tampaknya tepat sekali untuk menyimak fungsi Baris sakral di Desa Adat Penglipuran. Fungsi ini tetap dipertahankan hingga sekarang ini, meskipun Penglipuran telah menjadi daerah tujuan wisata. Untuk menegaskan pendapat Soedarsono (1985:18) yang mengatakan bahwa di Bali perkembangan fungsi ritual seni pertunjukan banyak terjadi perubahan, seperti tari pendet dan tari gabor yang fungsi aslinya adalah tari yang agak sakral untuk para dewa dan dipertunjukkan di bagian pura paling dalam dan suci, karena pengaruh pariwisata bertambah fungsinya menjadi tari penyambutan untuk tamu-tamu agung. Sekali lagi dapat digarisbawahi bahwa kasus tari Baris sakral ini ternyata tidak demikian, sebab fungsinya semula masih dipertahankan sampai sekarang.

\section{Fungsi Ekspresi Seni Sebagai Konsep Ngayah}

Setiap anggota masyarakat yang sebagai pendukung pementasan Tari Baris Sakral, adalah juga tidak dapat dipisahkan dengan sekaa tabuh atau mereka yang memainkan gambelan sebagai pengiring setiap jenis tari Baris yang akan dipentaskan. Setiap pendukung pementasan Tari Baris Sakral tersebut mempunyai nilai atau keinginan untuk gaturang ayah sebagai perwujudan rasa bakti kepada Tuhan Yang Maha Esa dalam kaitannya dengan pelaksanaan upacara Dewa Yadnya. Pementasan Tar Baris Sakral di Desa Adat Penglipuran sudah merupakan bagian dari rangkaian upacara Dewa Yadnya, sehingga baik penari maupun penabuh dengan sendirinya mereka terlibat dalam proses upacara melestarikan nilai-nilai spiritual dari Tari Baris Sakral yang ada. Ini berarti fungsi tari Baris sakral tersebut sebagai wahana pemujaan kepada Ida Sanghyang Widhi Wasa, khususnya pada waktu upacara piodalan.

\section{Fungsi Sosial Tari Baris di Penglipuran}

Fungsi sosial Baris sakral penekanannya adalah pada beberapa aspek di luar struktur intrinsik, namun menjadi inti dari karya seni. Oleh karena Baris sakral itu dipentaskan, maka pementasan itu tentu melibatkan beberapa aspek sosial di luar seni. Sebagai sebuah kesenian Bali secara fungsional dapat digolongkan menjadi tiga kelompok, yakni, (1) tari wali 
(sacred religious dance), (2) tari bebali (ceremonial dance), dan (3) tari balih-balihan (secular dance). Untuk itu Anthony Shay sebagaimana dikutip Bandem (1996:28) menyebutkan enam fungsi tari, yakni Pertama, tari sebagai refleksi dan validasi organisasi sosial. Kedua, tari sebagai alat untuk upacara keagamaan dan juga untuk aktivitas sekuler. Ketiga, tari sebagai aktivitas kreatif. Keempat, tari sebagai ungkapan kebebasan rasa. Kelima, tari sebagai ungkapan keindahan atau pun aktivitas keindahan itu sendiri. Keenam, tari sebagai refleksi dari pola perekonomian atau aktivitas ekonomi. Dalam aktivitas kesenian di Bali sesekuler apapun bentuk seni itu tidak dapat dilepaskan dari sebuah konsep religiusitasnya. Hal ini dapat dilihat dari pemilihan judul lakon yang pada umumnya mengambil tema sentralnya adalah masalah rua bhineda yang sangat mendasar dialami oleh seluruh umat manusia di muka bumi ini. Konflik antara kebaikan dan kejahatan melukiskan secara visual oleh gerak dan penggambaran kejadian serta watak secara ekspresif dibantu oleh musik atau gamelan perpaduannya merupakan medium audio-visual yang dalam ketunggalannya menggelarkan, memperlihatkan suatu "drama" kehidupan (Asmara,1978:17).

Jika dilihat dalam perspektif kebudayaan Bali, maka tampaknya empat hal yang perlu dipertimbangkan dalam rangkaian "pelestarian sosialbudaya" masyarakat Bali adalah agama Hindu, adat-istiadat, bahasa dan sastra, dan kesenian. Dari keempat aspek tersebut ternyata seni tari menyangkut keempat aspek itu dalam Baris sakral khususnya. Agama terlihat dalam penggarapan tema, bahasa disimak melalui penggunaan bahasa (isyarat) dengan berbagai adat-istiadat terlihat pada tradisi rias, pakaian, cara berprilaku. Dengan demikian keempat aspek tersebut dapat digambarkan sebagai berikut.

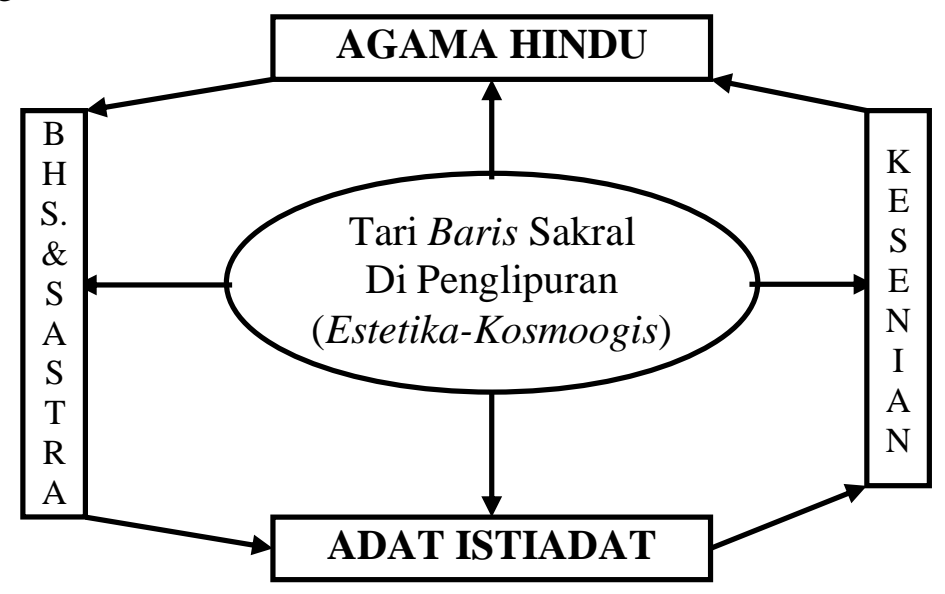

Baris Presi, Jojor, dan Bedil sebagai sebuah bentuk seni pentas yang bersifat sakral. Berbeda dengan teater klasik lainnya, Baris sakral ini semata-mata pemujaan terhadap dewa-dewi. Baris sakral sebagai pengu- 
kuhan institusi sosial terkadang dapat menyentuh hati nurani para penonton dengan konsep kepercayaan orang Penglipuran. Di situlah hiburan rohani, pengayaan moralitas agama, serta tata krama sosial kemasyarakatan diungkapkan dengan penuh estetika dramatik. Seni tari sebagai wahana penyampaian pesan-pesan ataupun kritik sosial memang cukup ampuh, oleh karena ungkapan seorang pemeran tokoh sakral kerapkali menjadi ungkapan yang sifatnya getok tular. Sentilan, sindiran dengan media bahasa estetik khas Baris sakral akan mampu merasuk ke dalam relung hati masyarakat Penglipuran itu sendiri. Dari gerak-gerik, percakapan-percakapan atau dialogdialog isyarat tersebut dapat ditangkap tentang keadaan politik dan sosial, pandangan hidup pada umumnya (Jassin,1953:50).

\section{Fungsi Estetika Hindu Baris Sakral}

Semua benda atau peristiwa seni atau kesenian pada hakikatnya mengandung tiga aspek yang mendasar, yakni (1) wujud atau rupa (appearance), (2) bobot atau sisi (content, substance), dan (3) penampilan atau penyajian (presentation). Wujud menyangkut bentuk (form) dan susunan atau struktur. Bobot mempunyai tiga aspek yaitu suasana (mood), gagasan (idea) dan pesan (message), sedangkan penampilan menyangkut tiga unsur yaitu bakat (tallent), keterampilan (skill) dan sarana atau media (Djelantik, 1999: 17-18). Jika komunitas seni menganggap seni sebagai suatu pengabdian kepada Ida Sanghyang Widhi, maka tidak mengherankan banyak seniman mempunyai lelakon "ngayah ngigel atau ngayah masolah", ketimbang sebagai seniman bayaran. Sebuah aktivitas seni mempunyai fungsi horisontal, yakni berusaha menghibur masyarakat sekuat kemampuan yang dimiliki oleh sang seniman dan fungsi vertikal, yakni ngayah kepada Ida Betara atau Tuhan. Jika kedua hal ini berhasil dilakoni, disitulah seorang seniman dikatakan metaksu. Sang seniman merasa puas jika mampu mempersembahkan aktivitas seninya pada masyarakat dan pada Tuhan. Dengan demikian, sang seniman merasa telah menjalankan dharma bhaktinya untuk kemanusiaan yakni mautsaha agawe sukaning len (berusaha menyenangkan orang lain), yang pada giliranya agawe sukanikanang rat (membuat kesenangan jagatdita) dengan falsafah Satyam (kebenaran), Siwam (kesucian) dan Sundaram (keindahan); kebenaran yang suci dan seni/indah, kesucian yang benar dan seni/indah, seni/indah yang benar dan suci. Tri wisesa ini merupakan sukma dari kesenian Bali yang bercorak religius Hindu dan religius filosofis. Ini adalah konsep arts and peace pada pengertian yang luas. Dengan demikian konsepsi keindahan dalam kebudayaan dan agama Hindu memiliki implikasi yang sangat kompleks dan terkait satu sama lain. Agama Hindu tanpa sentuhan estetika mungkin terasa kering, sebaliknya seni tanpa agama terasa kehilangan rohnya. 


\section{Makna Ekspresi Seni Bagi Desa Adat Penglipuran Sebagai Pemujaan}

Berdasarkan hasil analisis data seperti yang telah diuraikan di atas, Tari Baris Sakral yang merupakan tari penyelenggara upacara Dewa Yadnya di Desa Adat Penglipuran, mengandung makna atau unsur-unsur nilai spiritual di dalamnya. Hal itu tercermin dari ungkapan yadnya itu sendiri adalah suatu persembahan suci secara tulus iklas yang diwujudkan dalam bentuk upacara agama. Persembahan suci ini dapat terwujud dalam kesungguhan masyarakat Desa Adat Penglipuran untuk melaksanakan upacara yang dilandasi oleh rasa kebersamaan dan asas pengabdian oleh warga dan penabuh, dalam rangkaian upacara DewaYadnya. Upacara di samping dapat dilihat dalam bentuk fisik berupa upakara-upakara bebanten (sajen), juga lebih dari itu, sebenarnya mengandung pengertian filosofis yang mendalam, dimana terkandung nilai estetika, yaitu seni, nilai etika: moral dan nilai agama/spiritual.

Dari ketiga aspek nilai tersebut di atas, maka makna spiritual dari pementasan Tari Baris Sakral, ditunjukkan dengan adanya persembahyangan bersama yang dilakukan oleh para penari setelah menarikan serangkaian Tari Baris Sakral, yaitu Tari Baris Jojor, Tari Baris Presi dan Tari Baris Bedil, dengan menggunakan sarana sesajen yang sudah disiapkan berupa pendetan. Apabila ditinjau dari makna estetika, yaitu seni dari pementasan Tari Baris Sakral itu, maka dapat menumbuhkan apresiasi seni bagi masyarakat Desa Adat untuk melestarikan seni budaya warisan leluhur, sekaligus dapat memenuhi panggilan suci dalam mempersembahkan tari kepada Sang Pencipta sebagai tari penyelenggara upacara Dewa Yadnya. Untuk selanjutnya dicoba untuk memberikan gambaran mengenai makna dari penjelasan tersebut secara lebih teliti.

\section{Makna Teologis Baris Sakral}

Baris Presi, Jojor, dan Bedil sebagai seni sakral dibangun melalui proses tertentu, sehingga dapat memilki suatu kekuatan tertentu bagi masyarakat pendukugnya. Baris sakral yang melalui proses pelaksanaan yang sedemikian rupa menurut tata cara agama, dikramatkan serta dilakukan pementasan di tempat suci. Untuk Baris sakral ini dapat dipentaskan pada upacara piodalan khusus di tempat suci/pura utama. Di samping Baris sakral dipentaskan di Pura kahyangan jagat di Penglipuran, juga di Pura kahyangan Jagat seperti Pura Kehen, Batur dan Besakih.

Tari Baris yang dikenal sebagai salah satu peninggalan kesenian pra-Hindu, yang sekarang telah dikombinasikan oleh agama Hindu dan dijadikan seni sakral, seperti dimaksud dan kemudian fungsinya pun tidak berubah dari semula. Tari Baris ini diperkirakan telah ada sejak abad ke-9 menurut lontar Usana Bali (Rota dkk,1977:36; Bandingkan Simpen,1958: 12-13). Tari Baris yang telah didominasikan Hindu ini tidak beralih kepada fungsi lain, dalam arti fungsinya tetap seperti di atas, karena segala proses 
dan segala aktivitasnya menurut dan tak lepas dari aspek ritual keagamaan Hindu. Hal ini telah melaksanakan dharmaning agama. Demikianlah aktivitas Baris sakral ini yang berfungsi sebagai dharmaning agama, sebagai pelaksanaan upacara agama Hindu dalam perspektif teologi lokal di Desa Adat Penglipuran.

Dari uraian di atas dapat dijelaskan bahwa makna Baris Sakral di dalam kehidupan masyarakat Desa Adat Penglipuran adalah suatu pertemuan atau pertaruangan (perang), penghormatan kepada leluhur (Bayung Gede), dan penghormatan kepada Ida Sanghyang Widhi yang telah menciptakan sebuah kehidupan. Kemudian ditarikan dengan sangat hikmat dan penuh ekspresi religius, pada akhir dari pementasan Baris Sakral sekaligus sebagai rangkaian upacara, untuk mohon kesejahteraan, kemuliaan, dan keselamatan. Untuk Baris Sakral ini mempunyai kekhasan tersendiri dari tari Baris yang lainnya, pada saat ditarikan penari Baris ini harus dari golongan tertentu yang termuat dalam awig-awig Desa, sebagaimana telah diungkapkan di atas.

Dengan paparan pemaknaan tersebut di atas, maka secara teologi lokal ritual tari Baris sakral mengandung makna teologi yang cukup tinggi bagi peradaban orang Penglipuran. Konteks teologinya merupakan perpaduan antara konsepsi Hindu universal dengan konsep pemujaan leluhur mereka, bagi Penglipuran poros kosmologinya berkiblat ke Desa Bayung Gede, Kintamani. Lihat Bagan di bawah ini sebagai berikut.

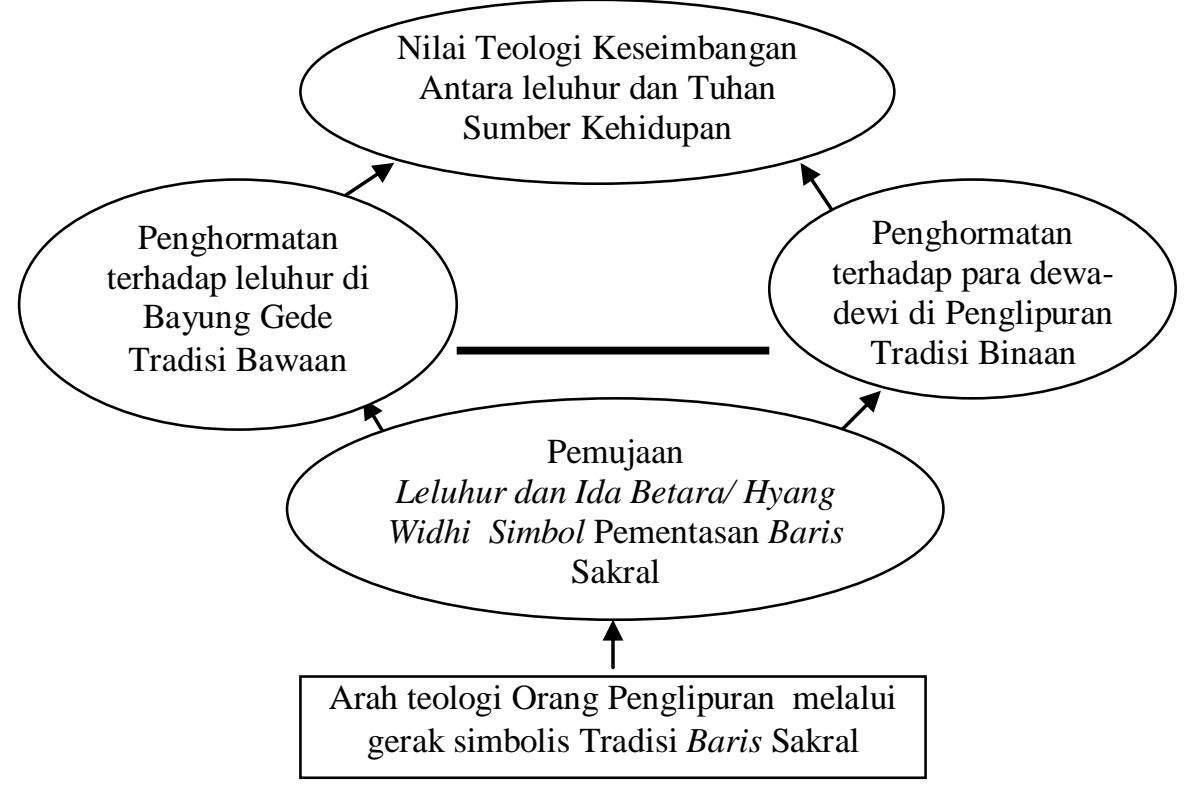

Masyarakat Penglipuran memiliki kepercayaan sebagai landasan teologis kepada realitas Ida Sanghyang Widhi yang harus menjadi titik sen- 
tral kehidupan masyarakat Penglipuran. Konsep pemujaannya mempergunakan sebuah tradisi seni Baris Sakral untuk mengukuhkan konsepsi keseimbangan kosmologis yang dipersepsikan sebagai asal muasal kehidupan di dunia ini. Dengan Baris Sakral sebagai personifikasi dari konsep tersebut dipentaskan dengan berbagai syarat ritual untuk bisa mencapai kesempurnaan upacara ritual itu sendiri. Arah ujung dari pemujaan ini adalah tercapainya keseimbangan kehidupan para dewa-dewi dan manusia di dunia nyata. Tujuan ini merupakan upaya mengharmoniskan konsep Tri Hita Karana, agar hidup ini tidak mengalami disharmonis yang menimbulkan mala petaka. Secara universal sesungguhnya hakikat pemujaan itu adalah sungguh tercapainya keseimbangan lahir-batin dari kehidupan manusia di dunia dan di akhirat.

\section{Makna Kesuburan Baris Sakral Di Desa Adat Penglipuran}

Baris Sakral dalam kaitanya dengan hakikat kehidupan masyarakat Penglipuran sesungguhnya merupakan "pemeliharaan" dan pemanfaatan bumi (ibu pertiwi) dan air. Dalam cerita lahirnya Sang Boma yang lahir dari Dewa Wisnu (air) dengan Pretiwi (tanah), maka Boma dapat diartikan sebagai hutan atau tumbuhan. Tumbuhan-tumbuhan lahir dari tanah dan air dan tumbuh di atas tanah atau ibu pretiwi. Masyarakat Penglipuran sangat memelihara aspek lingkungannya khususnya hutan bambunya dan tumbuhan lainya. Konsep perlindungannya dituangkan dengan aktivitas seni ritual. Dalam konsep harmoni yang menjadi falsafah hidup orang Hindu Bali adalah Tri Hita Karana (tri=tiga, hita= kebahagiaan, dan karana=penyebab), yakni menyangkut hubungan manusia dengan Tuhan, hubungan manusia dengan manusia dan hubungan manusia dengan alam. Dengan demikian dapat digambarkan konsep harmoni yang bersifat totalitas, yakni perpaduan antara vertikal (Tuhan) dan horisontal (manusia dan alam). Ketiga aspek ini memunculkan bentuk-bentuk hubungan yang berkaitan dengan sistem pemujaan, sistem kekerabatan, dan sistem kemasyarakatan dalam masyarakat Penglipuran.

Baris Sakral sebagai bagian dari sistem pemujaan dalam konteks tri hita karana merupakan sebuah kesatuan hubungan, yakni hubungan warga Penglipuran dengan Tuhan (aspek teologis), hubungan warga Penglipuran dengan sesama (aspek sosiologis) dan hubungan warga Penglipuran dengan wilayah/ lingkungannya. Kesemuanya itu merupkan satu-kestuan makna, yakni intensitas "pemeliharaan" dalam arti yang sangat luas. Jika salah satu dari ketiga unsur itu sudah tidak terpelihara, maka unsur yang lainnya lambat laun akan mengalami kemunduran.

Hakikat Baris Sakral sebagai bagian dari sistem keharmonisan hidup menurut falsafah hidup umat Hindu di Bali khususnya masyarakat Penglipuran adalah ritus kesuburan yang membawa kesejahteraan masyarakat. Secara teologi seperti apa yang telah dijelaskan di atas telah dapat diduga 
bahwa Baris Sakral ini berorientasi pada nilai kesuburan. Baris Sakral adalah simbol permohonan akan kesuburan/permohonan hujan untuk kesejahteraan umat manusia. Di samping itu, tarian ini juga memiliki makna "pemertahanan" wilayah dari serangan orang luar yang ingin merusak tatanan desa Adat Penglipuran.

Dengan ritual ini dilaksanakan dengan berbagai pengharapan akan terciptanya kedamaian, kesejahteraan, serta kesuburan kembali tanah Penglipuran adalah sebagai bentuk pemusatan pemikiran orang Penglipuran kepada Ida Sanghyang Widhi. Proses ritual ini meskipun kelihatannya agak monoton, namun simbolisasi dibalik peristiwa tersebut adalah hakikat kehidupan manusia secara universal khususnya umat Hindu. Jika ritual ini sukses, maka diyakini secara teologis dan sosiologis masyarakat Penglipuran akan mencapai keseimbangan, kesejahteraan, dan terpeliharanya norma sosial keagamaan dari generasi ke genarasi secara berkesinambungan.

\section{Makna Untuk Lingkungan Sosial}

Makna Untuk lingkungan yang dimaksudkan di sini adalah ternyata ritual Baris Sakral merupakan pemeliharaan alam lingkungan dua tradisi, yaitu perantauan (Bayung Gede) dan Penglipuran Sekarang. Berbagai profesi, status sosial yang ikut terlibat sesungguhnya upaya pelestarian lingkungan Desa Penglipuran. Mitos gunung yang keras melahirkan tradisi seni yang sifatnya "perang" sebagaimana makna Baris Presi sebagai seni "menyerang". Ini berarti masyarakat Penglipuran ingin mempertahankan daerahnya dari kekuasaan, kerusakan yang ditimbulkan oleh orang lain.

Bentuk ritual Baris sakral juga mencerminkan pemeliharaan lingkungan, seperti penggunaan kostum, bentuk dan bahan sesajen semuanya mencerminkan tradisi setempat. Meskipun Penglipuran sekarang telah tersentuh oleh dunia pariwisata, namun tradisi ritual lingkungan ini masih tetap dipertahankan. Hal inilah yang sesungguhnya merupakan benteng spiritual orang Penglipuran untuk mempertahankan eksistensi dirinya dengan membulatkan tradisi keagamaannya dengan seni keagamaan untuk memusatkan seluruh perhatian, pemikiran untuk kebesaran Ida Sanghyang Widhi Wasa.

Upaya pelestarian tari sakral di Desa Adat Penglipuran merupakan upaya untuk tetap mempertahankan keadaan semula, dan tidak mengalami perubahan, sebagai salah satu peninggalan sejarah, yang mempunyai nilainilai agama Hindu dan nilai spiritual tinggi. Bali yang memiliki unsur estetika yang cukup unik dan kompleks menyebabkan daya tarik Bali sebagai daerah tujuan wisata semakin mendunia. Keindahan Bali dapat mencakup aspek-aspek, seperti yang dikemukakan oleh The Liang Gie (1976:35), yaitu: keindahan seni, keindahan alam, keindahan moral, dan keindahan intelektual. Dua aspek keindahan terakhir menyangkut kaidah estetika yang ber sumber pada agama Hindu. Keindahan moral menyangkut sikap dan peri- 
laku masyarakat Bali berdasarkan ajaran agama Hindu, demikian juga keindahan intelektuil tercermin pada makna gagasan yang menjadi isi dari setiap seni yang tercipta. Estetika adalah salah satu unsur yang penting dalam hidup manusia. Ia menggerakkan manusia ke arah konstruktif dalam berbagai lapangan hidup, antara lain kepada rasa jengah yang berlandaskan Rajasika dan Satwika (Mantra,1991:12).

Landasan Rajasika dan Satwika ini merupakan dasar-dasar yang meletakkan hubungan keindahan dengan esensi agama Hindu sebagai "Roh" karya seni yang lahir dan berkembang di Bali. Kesenian Bali telah berkembang begitu pesatnya, seiring dengan perkembangan dunia pariwisata, maka dampak dari perkembangan pariwisata tersebut, munculah kreativitas seni yang mencoba untuk memperindah pulau Bali itu sendiri. Di samping memiliki nilai religius, seni pertunjukan keagamaan mempunyai juga nilai Magis, dan proses penciptaannya sering dikaitkan dengan konsep pengider buwana (Bandem,1996:37). Di samping itu, pulau Bali sesungguhnya secara religius merupakan benteng spiritual yang sangat kokoh, oleh karena getaran religiusitas itu sesuai dengan konsep mata angin (pangider bhuwana), telah menempatkan pura sebagai dasar yang kuat. Konsepsi penempatan pura di Bali tidak saja menggunakan konsep pengider bhuwana, tetapi juga tinggi-rendah (Sagara-Wukir) sebagai ruang kosmis yang memiliki kekuatan magis-religius. Oleh karena itu, di Bali dikenal dengan konsep arah luanteben, dimana luan sebagai hulu yang diorientasikan sebagai daerah yang tinggi kaadya (gunung), dan teben sebagai hilir yang diorientasikan pada laut. Bahkan arah yang dianggap paling suci adalah kaja-kangin atau timur laut. Inilah hakikat dari estetika Hindu di Bali dimana Pura, seni menjadi titik sentral pemujaan terhadap Tuhan. Perpaduan antara nilai agama Hindu, estetika, dan kemampuan masyarakat menyebabkan banyak tradisi pemujaan yang muncul lewat estetika atau seni.Cara pandang orang Bali terhadap alam sakral dan alam profan masih berpengaruh pula dalam keseniannya. Orientasi arah kaja (utara) dan kelod (selatan), kepercayaan kepada adanya siwaloka (wilayah kekuasaan Dewa Siwa dalam jagat raya) dan yamaloka (wilayah kekuasaan Dewa Yanm dalam jagat raya), kepercayaan kepada luanan (wilayah depan, lebih suci) dan tebenan (wilayah belakang, tidak suci). Tari-tarian ditempatkan pada aksis tertentu dari tri mandala. Tari sakral dipentaskan di jeroan (bagian paling dalam, bagian utama), tari bebali di pentaskan di jaba tengah (bagian tengah, madya), dan tari balih-balihan di pentaskan di jaba sisi (bagian paling luar, bagian nista). Pembagian ruang ini telah memberikan corak seni yang sangat khas dan memiliki makna sesuai dengan ruang tersebut (Bandem,1996: 34).

\section{Makna Seni Dalam Perubahan Budaya}

Meskipun dalam sejarah fungsi tertua seni pertunjukan adalah untuk upacara, kemudian di susul yang berfungsi sebagai hiburan pribadi, dan ter- 
akhir sebagai tontonan, namun pada zaman modern yang penuh perubahan ini fungsi seni pertunjukan yang paling tua masih ada yang lestari, ada yang fungsinya bergeser meskipun bentuknya tidak begitu berubah, dan ada yang fungsinya bergeser serta bentuknya berubah atau tumpang tindih. Di samping itu, sudah barang tentu terdapat pula bentuk-bentuk baru akibat kebutuhan dan kreativitas manusia (Soedarsono,1985:18). Perubahan ini salah satunya disebabkan oleh pesatnya pariwisata di Bali. Di antara dampak negatif dari pariwisata adalah terjadinya komersialisasi yang merendahkan harga diri budaya tradisi, menjauhkan dan menghilangkan identitas budaya, merusak tradisi lokal dan pandangan hidup. Penyalahgunaan tradisi, meningkatkan perebutan keuntungan, perselisihan atas hak tanah, hilangnya keaslian nilai-nilai sejarah (Ardika,2002:4). Selain itu, pariwisata juga mengakibatkan di satu sisi mendorong kesemarakan, di sisi lain menghadap-kan tantangan pada umat Hindu di Bali dalam mempertahankan kesakralan budaya dan agama Hindu. Ada yang terlalu tenggelam dalam keuntungan yang diberikan oleh pariwisata, larut dalam pikiran yang beorientasi pada PAD sehingga kadang-kadang lupa bahwa untuk mempertahankan gaya ta-rik kepariwisataan Bali wajib menjaga kesakralan Bali itu sendiri (Goda, 2002:9).

Modernisasi dan pembangunan di dalam dua dekade terakhir ini telah membawa masyarakat kontemporer ke dalam berbagai sisi realitas-realitas baru kehidupan, seperti kenyamanan, kesenangan, keterpesonaan, kesempurnaan penampilan, kebebasan hasrat. Akan tetapi, modernisasi dan pembangunan itu sebaliknya telah menyebabkan kehilangan realitas-realitas masa lalu beserta kearifan-kearifan masa lampau yang ada di baliknya, yang justru lebih berharga bagi pembangunan diri sebagai manusia, seperti rasa kedalaman, rasa kebersamaan, rasa keindahan, semangat spiritualitas, semangat moralitas, dan semangat komunitas (Piliang,1999:29).

Jika apa yang ditegaskan itu benar, maka konsekuensinya adalah akan terjadi perubahan tatanan masyarakat, dari konsep lokal, nasional, dan global. Perubahan tersebut tidak saja akan muncul di permukaan sebagai ciri dari budaya kapitalistik, namun juga akan merasuk pada perilaku (ideologi). Tampakanya perubahan sebagai ekses dari globalisasi sungguh sulit dihindari, namun perubahan tersebut hendaknya betul-betul disadari sebagai konsekuensi logis dari sistem budaya global dan perubahan yang dikehendaki bukanlah perubahan yang menjungkir-balikan nilai-nilai, normanorma yang telah mantap dan berakar di dalam masyarakat yang berbudaya, melainkan cakupannya terbatas yang termodifikasi dengan beradaptasi secara bertahap. Di sinilah dunia spiritual (agama) erat kaitanya dengan kebudayaan yang terus mengalami perubahan. Dengan demikian, maka hubungan antara agama dan kebudayaan sangatlah erat. Agama sebagai perhatian pokok merupakan substansi budaya yang memberikan makna dan budaya merupakan totalitas bentuk-bentuk di mana perhatian dasar agama 
mengungkapkan dirinya. Pendeknya agama adalah substansi budaya, budaya adalah bentuk agama (Tillich,2002:49).

Berdasarkan konsep perubahan kebudayaan seperti itu, tampak seni keagamaan sesungguhnya mengalami tantangan yang cukup berat. Tantangan itu adalah di satu sisi proses regenerasi berada pada generasi yang modern, kemudian pendidikannya memerlukan pemahaman sebuah tradisi yang tunduk pada sebuah kekuatan yang di atas (Tuhan). Namun demikian, dengan berpegang teguh pada kekuatan keagamaan (Hindu), maka tradisi seni keagamaan akan tetap eksis. Seni dan agama Hindu umumnya dan di Bali khususnya sangat erat dan saling mengisi. Agama Hindu adalah sebagai sumber segala karya seni di Bali dan sebagai pendorong inspirasi dari segala karya kreatif dalam masyarakat Bali. Hanya baru sekaranglah baru tampak pengaruh dari karya seni yang bersumber kepada penghidupan rakyat sehari-hari (Mantra,1991:18). Hal ini dipertegas lagi oleh I Gusti Bagus Sugriwa (1952:22) bahwa kesenian Bali atau seni budaya suku BaliHindu yang hidup bergolak sampai sekarang, pada hakikatnya adalah anak atau cabang ranting dari agama Hindu Bali. Kesenian dengan agama ini mempunyai hubungan yang amat erat pada umumnya tidak dapat dipisahkan satu sama lainya. Tegasnya jika agama Hindu Bali itu musnah dari nusa Bali ini, tak dapat tiada lambat-bangatnya kesenian Bali-Hindu yang meliputi seni sastra, seni nyanyi, seni tari, seni ukir, seni rupa dan lukis dan bunyi-bunyian pun akan turut parama satia membunuh dirinya. Sebaliknya bila kesenian Bali-Hindu itu hilang, mungkin pula agama Hindu-Bali itupun gaib juga.

\section{SIMPULAN} berikut.

Berdasarkan analisis permasalahan di atas, simpulannya sebagai

Bentuk pementasan seni di Desa Penglipuran, yaitu Tari Baris Sakral sebagai salah satu bentuk seni tradisional yang berakar kuat pada kehidupan masyarakatnya dan hidup secara mentradisi atau turun temurun, dimana keberadaan Tari Baris Sakral di Desa Adat Penglipuran adalah merupakan tarian yang langka, dan berfungsi sebagai tari penyelenggara upacara dewa yadnya. Adapun iringan gambelan yang mengiringi pada saat pementasan semua jenis Tari Baris Sakral tersebut adalah seperangkat gambelan Gong Gede yang didukung oleh Sekaa Gong Gede Desa Adat Penglipuran. Unsur bentuk ini meliputi juga: keanggotaan sekaa Baris sakral ini di atur di dalam awig-awig Desa Adat Penglipuran. Kemudian nama-nama penari ketiga jenis Baris sakral ini juga telah ditetapkan, yakni Baris Jojor 12 orang, Baris Presi 12 orang, dan Baris Bedil 20 orang. Bentuk Pendidikan seni keagamaan ini melalui pembentukan sekaa tari dan sekaa tabuh yang diambil dari krama desa Adat penglipuran sesuai dengan ketentuan yang berlaku. Tari Baris Sakral adalah sebagai seni tradisional 
yang keberadaannya sangat langka, sehingga Desa Adat Penglipuran berupaya melestarikan nilai-nilai spiritual yang terkandung dalam pementasan Tari Baris Sakral dengan cara melaksanakan pementasan pada setiap ada upacara Dewa Yadnya di Desa Adat Penglipuran, disamping itu juga mengadakan regenerasi pendukung tari Baris kepada generasi muda yang mempunyai bakat seni, bak seni tari maupun seni tabuh, yang kesemuannya itu dihmpun dalam bentuk Sekaa Tari Baris dan Sekaa Gong.

Fungsi pementasan seni Baris sakral ini adalah sebagai sarana pelengkap upacara agama Hindu khususnya saat piodalan di kahyangan tiga setempat. Kemudian fungsi sebagai ayah-ayahan yang muncul dari lubuk hati masyarakatnya. Hal ini sebagai bentuk tanggungjawab kepada Ida Sanghyang Widhi. Di samping itu juga memiliki fungsi sosial dalam hubungannya kekerabatan antarkrama adat di lingkungan Penglipuran (perekat sosial). Selain itu, yang terpenting adalah fungsi estetika, yakni sebagai hiburan rohani dan spiritual. Pementasan semua jenis Tari Baris Sakral yang ada di Desa Adat Penglipuran adalah mempunyai nilai-nilai spiritual dan filosofi yang sangat mendalam sebagai tari penyelenggara upacara Dewa Yadnya.

Berkaitan dengan aspek makna Pementasan seni ini memiliki makna: makna teologis dalam arti berkaitan dengan sistem pemujaan dan hakikat pemujaan baik pada leluhur maupun kepada Ida Sanghyang widhi. Makna kesuburan artinya pementasan itu memiliki dimensi untuk memohon kesuburan, kesejahteraan, kedamaian kepada Tuhan. Ini sebagai ekspresi ritualistik pada masyarakat agraris. Makna lingkungan sosial artinya secara sosiologis tari ini merupakan refleksi pemeliharaan hubungan manusia sesama manusia, lingkungan, dan Tuhan. Akhirnya pendidikan seni keagamaan ini akan memiliki makna antara kebertahanan dan perubahan seiring dengan perubahan kebudayaan manusia.

\section{DAFTAR RUJUKAN}

Ardika, I Wayan, 2002. Kebijakan Pariwisata Budaya Dalam perspektif Budaya Bali. Makalah Sarasehan Seni Sakral. Denpasar: Dinas Kebudayaan Propinsi Bali.

Asmara, Andhy. 1978. Apresiasi Drama. Bandung: Penerbit Percetakan Timbul.

Bandem, I Made,1988. Ensiklopedi Tari Bali. Denpasar: Akademi Seni Tari Indonesia (ASTI).

1995. "Heroisme dalam Sastra babad di Bali. Sebagaimana yang tampak pada Seni Pertunjukan Topeng". Makalah Sarasehan Sastra Daerah Bali pada PKB XVII. Denpasar: Panitia Seminar. 1996. Etnologi Tari Bali. Yogyakarta: Kanisius.

Covarrubias, Miquel,1952. Island of Bali. London: Oxford University Press.

Dibia, I Wayan, 1997/1978. Perkembangan Seni Tari Bali. Denpasar : Proyek Sarana Budaya Bali. 
Ekspresi Seni Masyarakat... (I Nengah Duija)

, Kepribadian Bangsa “, Dalam Kebudayaan dan Kepribadian Bangsa, Editor Tjok Rai Sudarta. Denpasar, Upada Sastra. ,1999. Selayang Pandang Seni Pertunjukan Bali. Bandung: Masyarakat Seni Pertunjukan Indonesia.

Djelantik, A.A. Made,1999. Estetika Sebuah Pengantar. Bandung: Masyarakat Seni Pertujukan Indonesia.

Gie, The Liang, 1976. Estetika. Garis Besar Filsafat Keindahan. Yogyakarta: Kanisius ,1996. Filsafat Seni, Yogyakarta : Pusat Belajar Ilmu Berguna.

Goda, I Gusti Gede,2002. Alat-Alat Upacara Agama Hindu dalam Konteks Seni Sakral. Makalah Sarasehan Seni Sakral. Denpasar: Dinas Kebudayaan Propinsi Bali.

Jassin, H.B. 1953. Tipe Penyair dan Daerahnya. Jakarta: PT Gunung Agung.

Koentjaraningrat,1985. Beberapa Pokok Antropologi Sosial. Jakarta: Dian Rakyat.

Koentjaraningrat, 1987. Manusia dan Kebudayaan di Indonesia. Jakarta: Djambatan.

1990. Pengantar Ilmu Antropologi. Jakarta: Rineka Cipta.

Mantra, Ida Bagus,1991. Landasan Kebudayaan Bali. Denpasar: Yayasan Dharma Sastra.

Murdowo,1967. Seni Bali. Denpasar: Yayasan Seni Bali.

Pilliang, Yasraf Amir,1999. Sebuah Dunia yang Dilipat Realitas Kebuda-yaan Menjelang Millenium Ketiga Dan Matinya Posmodernisme. Bandung: Mizan.

Poerbatjaraka, R.Ng. 1978. Nitiçastra. Bibliotek Javanica. No.54. No. B.1483.

Rota, I Ketut dkk,1977. Pengantar Dasar Beberapa Tari Bali. Denpasar: Akademi Seni Tari Indonesia.

Sedyawati, Edi,1981. Pertumbuhan Seni Pertunjukan. Jakarta: Sinar Harapan.

Simpen, I Wayan AB,1958. Sejarah Bali. Denpasar: Pustaka Balimas.

Soedarsono, R.M,1985. Sejarah Kesenian. Pidato Pengukuhan Guru Besar. Yogyakarta: Universitas Gajah Mada.

Sugriwa, I Gusti Bagus, 1952. "Seni Budaya Hindu Bali”. Dalam Indonesia Nonor Bali, Majalah Kebudayaan. Jakarta: Lembaga Kebudayaan Indonesia.

Tillich, Paul.2001. Teologi Kebudayaan. Tendensi, Aplikasi \& Komparasi. Yogyakarta: IRCiSoD.

Zoetmulder, P.J.1985. Sastra Jawa Kuno, Selayang Pandang. Jakarta: Djembatan 